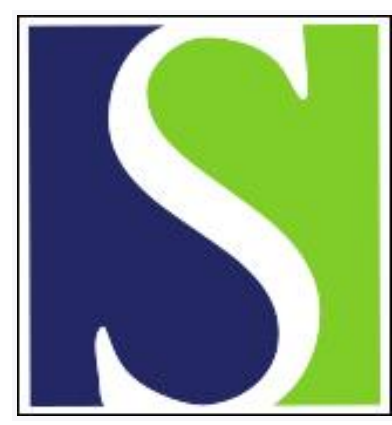

Scand J Work Environ Health 1987;13(4):301-304

https://doi.org/10.5271/sjweh.2036

Issue date: Aug 1987

\title{
Prevention of the hand-arm vibration syndrome.
}

by Saito K

Affiliation: Department of Hygiene and Preventive Medicine, Hokkaido University School of Medicine, Sapporo, Japan.

This article in PubMed: www.ncbi.nlm.nih.gov/pubmed/3433030

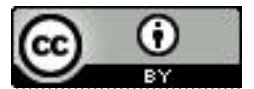




\title{
Prevention of the hand-arm vibration syndrome
}

\author{
by Kazuo Saito, MD, $\mathrm{PhD}^{1}$
}

\begin{abstract}
SAITO K. Prevention of the hand-arm vibration syndrome. Scand J Work Environ Health 13 (1987) 301-304. In order to determine the prevalence of the hand-arm vibration syndrome before preventive countermeasures were taken, a special health examination was carried out among 417 national forestry workers operating chain saws in the northern area of Hokkaido, Japan. Thirty-two chain-saw workers $(7.7 \%)$ were diagnosed as exhibiting the vibration syndrome. The highest prevalence rates were $15.8 \%$ among the workers who had operated the saws for 11 to 15 years and $20.3 \%$ for workers in their 50 s. Improved work conditions for chain-saw workers have increasingly prevented the vibration syndrome in the state forests of Japan since 1978. The present report covered the six years since 1978, and evaluated the effects of these improved work conditions on chain-saw workers from data on the recovery rates of skin temperature and the vibration sense threshold after a cold provocation test. As a result, recovery rates of skin temperature and the vibration sense thresholds at the fifth and tenth minutes after the immersion of the hands in cold water were significantly better than those six years earlier. It is suggested that adequate restrictions on the operating time of the chain saw and on the age of workers can completely prevent the vibration syndrome even if the total operating time is appreciably lengthened.
\end{abstract}

Key terms: prevalence, prevention.

It is well known that the hand-arm vibration syndrome occurs after the long-term operation of many kinds of vibrating tools and that cold in the work environment and noise induced by vibration tools are associated factors $(4,5,6,8,9,10,11,13,14,15,16)$.

Large numbers of forestry workers exhibiting the syndrome have been observed in mainland Japan since 1965. We have also experienced the same phenomenon in Hokkaido. In order to determine the incidence of the hand-arm vibration syndrome before preventive countermeasures were taken, a special health examination was carried out in 1978 among 417 national forestry workers operating chain saws in the northern area of Hokkaido. Thirty-two chain-saw operators $(7.7 \%)$ were diagnosed as suffering from the handarm vibration syndrome. The distribution of the cases, classified by the scheme of the Forestry Agency, Japan (3), was $50 \%$ in grade I, 31.2 \% in grade II, and $18.8 \%$ in grade III (table 1). Twenty-seven of the 32 authorized patients had been treated with periodic therapy and had been prohibited from chain-saw operation prior to this special health examination. The highest prevalence rate for workers with the hand-arm vibration syndrome was $20.3 \%$ for those in their 50 s, and $15.8 \%$ among those who had operated chain saws for 11 to 15 years (table 2).

The real work conditions of the chain-saw workers have been improved in the state forest of Japan since 1978 , so that the operators now work $2 \mathrm{~h}$ in the morning or $2 \mathrm{~h}$ in the afternoon per day, while one

1 Department of Hygiene and Preventive Medicine, Hokkaido University School of Medicine, Sapporo, Japan.

Reprint requests to: Dr K Saito, Department of Hygiene and Preventive Medicine, Hokkaido University School of Medicine, Nishi 7, Kita 15, Kita-ku, Sapporo 060, Japan. operating cycle lasts $10 \mathrm{~min}$ only. The operating time is less than $4 \mathrm{~d}$ a week, not more than $2 \mathrm{~d}$ continuously, less than $32 \mathrm{~h}$ a month, and less than $120 \mathrm{~d}$ a year (table 3). Improvements in the design of the chain saw have also led to a decrease in its vibration.

The effects of these alterations in the work conditions of forestry work on chain-saw workers were evaluated from data showing the recovery rates of skin temperature and the vibration sense threshold after a cold provocation test (immersion of the hand in cold water). The data were collected during special health examinations over a period of six years.

Table 1. Prevalence rate of the hand-arm vibration syndrome among chain-saw workers in the state forests of northern Hokkaido (total number of chain-saw workers 417 ).

\begin{tabular}{lcc}
\hline \multirow{2}{*}{$\begin{array}{l}\text { Severity of the } \\
\text { syndrome }\end{array}$} & \multicolumn{2}{c}{$\begin{array}{c}\text { Workers with } \\
\text { vibration syndrome }\end{array}$} \\
\cline { 2 - 3 } & $\mathrm{N}$ & $\%$ \\
\hline Grade 1 & 16 & 3.9 \\
Grade II & 10 & 2.4 \\
Grade III & 6 & 1.4 \\
Grade IV & 0 & 0.0 \\
\hline Total & 32 & 7.7 \\
\hline
\end{tabular}

Table 2. Operation time of chain-saw workers suffering from the hand-arm vibration syndrome in northern Hokkaido.

\begin{tabular}{lcrc}
\hline \multirow{2}{*}{$\begin{array}{l}\text { Operation time } \\
\text { (years) }\end{array}$} & $\begin{array}{c}\text { Total } \\
\text { number of } \\
\text { workers }\end{array}$ & \multicolumn{2}{c}{$\begin{array}{c}\text { Workers with } \\
\text { vibration syndrome }\end{array}$} \\
\cline { 3 - 4 } & & $\mathrm{N}$ & $\%$ \\
\hline $0-5$ & 191 & 13 & 6.8 \\
$6-10$ & 138 & 9 & 6.5 \\
$11-15$ & 57 & 9 & 15.8 \\
$16-20$ & 29 & 1 & 3.4 \\
$21-25$ & 2 & 0 & 0.0 \\
\hline
\end{tabular}


Table 3. Improvements made in the work conditions of chainsaw workers for the prevention of vibration syndrome in the state forests of Japan since 1978 .

\begin{tabular}{lr}
\hline & Maximum \\
\cline { 2 - 2 } One operation cycle & 10 minutes \\
Operating time per day & 2 hours \\
Consecutive operating days & 2 days \\
Operating days per week & 4 days \\
Operating hours per month & 32 hours \\
Operating days per year & 120 days \\
Nonoperating period for one year & 2 months \\
Age restriction & 55 years \\
\hline
\end{tabular}

Table 4. Finger (digit IV of the left hand) skin temperature of chain-saw workers at room temperatures of 20 to $23^{\circ} \mathrm{C}$.

\begin{tabular}{lccc}
\hline Year & $\begin{array}{c}\text { Mean } \\
\left({ }^{\circ} \mathrm{C}\right)\end{array}$ & $\begin{array}{c}\text { Standrad } \\
\text { error of } \\
\text { the mean }\end{array}$ & $\begin{array}{c}\text { Range } \\
\left({ }^{\circ} \mathrm{C}\right)\end{array}$ \\
\hline 1978 & 31.5 & 0.15 & $26.2-35.0$ \\
1979 & 31.3 & 0.11 & $26.0-34.5$ \\
1980 & 32.6 & 0.17 & $27.0-36.5$ \\
1981 & 32.2 & 0.17 & $26.0-35.6$ \\
1982 & 32.4 & 0.19 & $23.6-35.5$ \\
1983 & 32.0 & 0.19 & $22.1-34.9$ \\
\hline
\end{tabular}

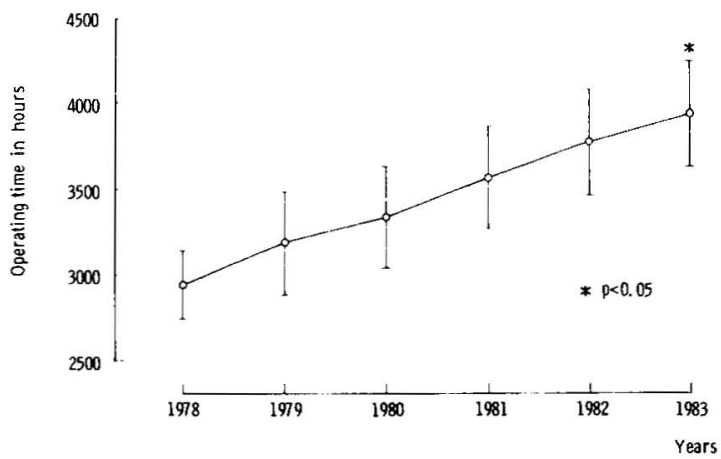

Figure 1. Changes in the operating time of chain-saw workers from 1978 to 1983

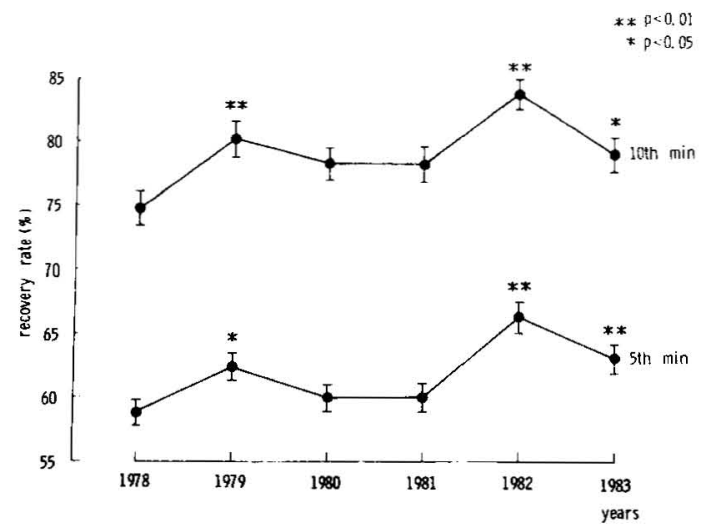

Figure 2. Changes in the recovery rates of skin temperature at the fifth and tenth minutes after immersion of the hands in cold $\left(10^{\circ} \mathrm{C}\right)$ water.

\section{Subjects and methods}

One hundred and fifty-five male chain-saw workers between the ages of 24 and 53 (mean 45.1, SE 0.6) years were studied. They were surveyed for their chain-saw operating times and their subjective symptoms for the six years from 1978 to 1983. Their skin temperatures, vibratory sense thresholds, recovery time of nail blood color in the nail compression test (17), and the pain sense of their fingers were measured annually at a room temperature of 20 to $23^{\circ} \mathrm{C}$ and at the fifth and tenth minute after a 10-min immersion of the hand in cold water at $10^{\circ} \mathrm{C}$. The data obtained from the six-year special health examinations given to the workers were analyzed to evaluate the effect of the new work conditions since 1978 .

\section{Results}

Changes in operating time, skin temperature and vibratory sense threshold of the workers

Figure 1 shows the changes in the operating time of the chain-saw workers who were engaged in the state forests of Hokkaido, Japan, from 1978 to 1983. The mean operating time of the workers increased from $2990 \mathrm{~h}$ in 1978 to $3944 \mathrm{~h}$ in 1983 . The increase in operating time over five years was significant.

Table 4 shows that the skin temperature of the chainsaw workers at a room temperature of 20 to $23^{\circ} \mathrm{C}$ did not reveal any significant difference by year, but that the recovery of skin temperature after the cold provocation test among men in their 20 s was faster than for other ages.

Details of changes in the recovery rate of skin temperature after the 10 -min cold provocation test are shown in figure 2 . The recovery rates at the fifth minute after the test were significantly better in 1982 and 1983 than in 1978 . Recovery rates at the tenth minute after the test were also significantly better in 1982 and 1983 than in 1978 . The values of the mean ages, operating times, and recovery rates of skin temperature for the chain-saw workers in 1983 are shown in table 5 .

The vibratory sense thresholds of the workers at the fifth minute after the cold provocation test were sig-

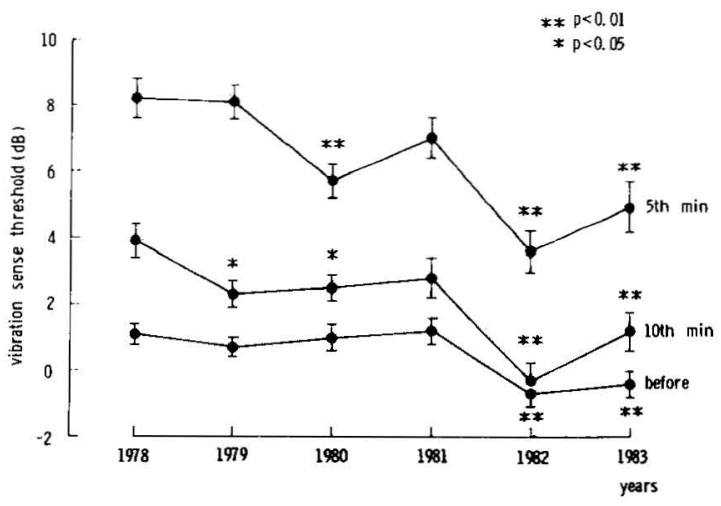

Figure 3. Changes in the vibration sense threshold of chain saw workers before and 5 and $10 \mathrm{~min}$ after immersion of the hands in cold $\left(10^{\circ} \mathrm{C}\right)$ water. 
nificantly better in 1980,1982 , and 1983 than in 1978; similarly the thresholds at the tenth minute after the test in $1979,1980,1982$, and 1983 recovered significantly (figure 3 ).

Table 6 shows the vibratory sense thresholds of the chain-saw workers in 1983. Analysis also showed significant differences by age under conditions of room temperature and at the fifth and tenth minute after the cold provocation test. The values of the vibratory sense thresholds among the older workers were markedly lower than those of the younger workers. The recovery of vibratory sense after immersion of the hands in cold water showed a tendency to be faster than that of their skin temperature.

In any case, the recovery of skin temperature and the vibratory sense threshold among the chain-saw workers has become progressively better since 1982, three years after improvements in the work conditions.

\section{Relationship of skin temperature and vibratory sense to age and operating time}

The correlation coefficients between the findings for age, operating time, and the recovery rates of skin temperature at the fifth and tenth minute after the cold provocation test are shown in table 7 . There are significant correlations between age and operating time in each year from 1978 to 1983 , between the recovery rates of skin temperature at the fifth and tenth minute after the cold provocation test in 1983, and between the recovery rates in every year from 1978 to 1983 . The correlations between the chain-saw operating time and skin temperature recovery rates after the cold provocation test were not significant. The correlations between age and the vibratory sense thresholds before and after the cold provocation test and between the values both before and after the test were positively significant, but the correlations between the chain-saw operating time and vibratory sense threshold were not significant (table 8).

\section{Discussion}

It is recognized that the operating time of vibrating tools affects the occurrence of the vibration syndrome. The chain saw was first used in Japanese forestry work to dispose of many trees felled by a typhoon in 1953 . Since then, the increasing mechanization of forestry processes has meant the increasing use of such tools. But for 20 years the operation time of vibrating tools was not limited, so that forest workers might well have operated for as many as $6 \mathrm{~h}$ a day. Between 1966 and 1969 , signs and symptoms of illnesses arising from the use of the power saw in forestry operations were reported from Japan, Sweden, and Australia (1, 2, 6, 7, 9). Taylor et al (16) reported that a marked increase in the prevalence of the hand-arm vibration syndrome was apparent over eight years among the chain-saw users in England. Pyykkö (13) reported that in eastern Finland $40 \%$ of 118 lumberjacks operating chain saws were found to have traumatic vasospastic disease and that the mean latency period of the patients was 5600 workhours and four years after the beginning of chainsaw operation. In our 1978 field study of the northern area of Hokkaido, Japan, the hand-arm vibration

Table 5. Age, operating hours, and recovery rate of skin temperature of digit IV of the left hand of 155 chain-saw workers after a cold provocation test in 1983.

\begin{tabular}{lrrc}
\hline & \multicolumn{3}{c}{$\begin{array}{c}\text { Standard } \\
\text { error of } \\
\text { the mean }\end{array}$} \\
\cline { 2 - 3 } & & & \\
\cline { 2 - 4 } & 45.1 & 0.6 & $29-58$ \\
$\begin{array}{l}\text { Age (years) } \\
\text { Operating time (h) }\end{array}$ & 3944.2 & 306.2 & $447-19899$ \\
$\begin{array}{l}\text { Recovery rate of the } \\
\text { skin temperature (\%) } \\
\text { After 5 min }\end{array}$ & 63.1 & 1.1 & $43.9-92.8$ \\
After 10 min & 79.1 & 1.3 & $50.2-111.2$ \\
\hline
\end{tabular}

Table 6. Vibratory sense threshold of digit III of the right hand of chain-saw workers in room temperatures of 20 to $23^{\circ} \mathrm{C}$ before and after a cold provocation test (immersion in cold water) in 1983. The threshold was measured with $125 \mathrm{~Hz}$ with an apparatus for measuring vibratory sense (Rion Model AU-02) (14). (dB re $308 \mathrm{~mm} / \mathrm{s}^{2}$ )

\begin{tabular}{lccc}
\hline & $\begin{array}{c}\text { Mean } \\
(\mathrm{dB})\end{array}$ & $\begin{array}{c}\text { Standard } \\
\text { error } \\
\text { of the } \\
\text { mean }\end{array}$ & $\begin{array}{c}\text { Range } \\
(\mathrm{dB})\end{array}$ \\
\cline { 2 - 4 } & -0.39 & 0.41 & $-10.0-15.0$ \\
$\begin{array}{l}\text { Before immersion } \\
\begin{array}{l}\text { Fifth minute after } \\
\text { immersion }\end{array}\end{array}$ & 4.94 & 0.79 & $-10.0-30.0$ \\
$\begin{array}{l}\text { Tenth minute after } \\
\text { immersion }\end{array}$ & 1.19 & 0.64 & $-10.0-27.5$ \\
\hline
\end{tabular}

Table 7. Correlation coefficients for age (A), operating time (O), and recovery rate of the skin temperature 5 (S5) and 10 (S10) min after a cold provocation test (immersion in cold water).

\begin{tabular}{|c|c|c|c|c|c|c|}
\hline Items & 1978 & 1979 & 1980 & 1981 & 1982 & 1983 \\
\hline $\begin{array}{l}A \text { vs } 0 \\
A \text { vs } S 5 \\
A \text { vs } S 10 \\
O \text { vs } S 5 \\
O \text { vs } S 10 \\
S 5 \text { vs } S 10\end{array}$ & $\begin{array}{l}0.3690^{* *} \\
-0.2901^{*} \\
-0.2009^{*} \\
-0.1010 \\
-0.0917 \\
0.8186 *\end{array}$ & $\begin{aligned} & 0.3559^{* *} \\
&- 0.1592 \\
&- 0.1713^{*} \\
&- 0.0853 \\
&- 0.0048 \\
& 0.8118^{* *}\end{aligned}$ & $\begin{array}{c}0.3520^{* *} \\
0.2824^{* *} \\
-0.1643 \\
-0.1032 \\
-0.0494 \\
0.7899^{* *}\end{array}$ & $\begin{array}{l}0.3545^{* *} \\
-0.2317^{* *} \\
-0.0523 \\
-0.1321 \\
-0.0087 \\
0.7981^{* *}\end{array}$ & $\begin{array}{c}0.3579^{\star \star} \\
-0.1956 \text { * } \\
-0.1191 \\
--0.1345 \\
-0.0953 \\
0.7867^{\star \star}\end{array}$ & $\begin{array}{l}0.3549^{* *} \\
-0.2336 \\
-0.1867^{*} \\
-0.1060 \\
-0.0574 \\
0.7940^{* *}\end{array}$ \\
\hline
\end{tabular}

* $P<0.05,{ }^{* *} P<0.01$. 
Table 8. Correlation coefficients for age $(A)$, operating time $(O)$, and vibratory sense thresholds before $\left(V_{0}\right)$ and $5\left(V_{5}\right)$ and 10 $\left(\mathrm{V}_{10}\right) \mathrm{min}$ after a cold provocation test (immersion in cold water).

\begin{tabular}{|c|c|c|c|c|c|c|}
\hline Items & 1978 & 1979 & 1980 & 1981 & 1982 & 1983 \\
\hline$A$ vs 0 & $0.3711^{* *}$ & $0.3579^{\star \star *}$ & $0.3540^{* *}$ & $0.3565^{* *}$ & $0.3600 * *$ & $0.3570^{* *}$ \\
\hline$A$ vs $V_{0}$ & $0.2885^{\text {* * }}$ & $0.3736^{* *}$ & $0.2210^{* *}$ & $0.2244^{\star *}$ & 0.1949 & $0.1893^{\star}$ \\
\hline$A$ vs $V_{5}$ & $0.2217^{\star \star}$ & 0.1589 & $0.1896^{\star}$ & 0.1543 & 0.0976 & $0.3061^{* *}$ \\
\hline$A$ vs $V_{10}$ & $0.1773^{\star}$ & 0.2281 ** & 0.0770 & 0.0482 & 0.0219 & $0.2780^{* *}$ \\
\hline$A$ vs $V_{0}$ & 0.1406 & 0.0383 & 0.0542 & 0.0868 & 0.0944 & -0.0567 \\
\hline$O$ vs $V_{5}^{0}$ & 0.0627 & 0.0315 & 0.0400 & 0.0464 & 0.0411 & 0.0927 \\
\hline$O$ vs $v_{10}^{5}$ & 0.0091 & -0.0415 & 0.0304 & 0.0156 & -0.0366 & 0.0540 \\
\hline$V_{0}$ vs $V_{5}$ & $0.2781^{* *}$ & $0.2610^{* *}$ & $0.3011^{* *}$ & $0.2938^{* \star}$ & 0.1584 & $0.2482^{* *}$ \\
\hline$V_{0}$ vs $V_{10}$ & $0.3029^{\star \star}$ & $0.3747^{\star *}$ & $0.2629 * *$ & $0.2106^{*}$ & 0.1633 & $0.3270^{* *}$ \\
\hline$V_{5}$ vs $V_{10}$ & $0.7953^{* *}$ & $0.6922^{\star \star}$ & $0.7449^{* *}$ & $0.7004^{* *}$ & $0.6911^{* *}$ & $0.8543^{* *}$ \\
\hline
\end{tabular}

${ }^{*} P<0.05,{ }^{* *} P<0.01$.

syndrome among 417 chain-saw workers was found to be $7.7 \%$. The peak duration of the operation time of the patients was from 11 to 15 years, and half the patients were over 50 years of age.

Of the 417 chain-saw workers, 155 were observed in special health examinations over a period of six years, apart from 32 patients with the hand-arm vibration syndrome. Their mean operation time for working the chain saws changed from 2990 to 3944 h over the six-year period after the official countermeasures had been taken in work conditions. They did not complain of any symptoms of the hand-arm vibration syndrome during this observation period.

Miyashita et al (12) have reported on the relationship between the progress of the vibration syndrome and the total chain-saw operating time among forestry workers. They showed that a group with 2000 to $5000 \mathrm{~h}$ of chain-saw operation had peripheral nerve and circulatory disturbances, including Raynaud's phenomenon, while even the group with less than $2000 \mathrm{~h}$ of experience complained of tingling, numbness, or pain and that the group with over $5000 \mathrm{~h}$ of exposure suffered severe functional, or organic changes owing to vibration. No special countermeasures to prevent the hand-arm vibration syndrome had been taken, however, until a special health examination was undertaken for an epidemiologic investigation.

Our results suggest that adequate countermeasures to restrict the operating time of chain saws and the age of the workers as shown in table 3 can completely prevent the hand-arm vibration syndrome even if the total operating time is appreciably lengthened.

\section{References}

1. Axelsson S. Analysis of vibration in power saws. Skogshögskolan, Stockholm 1968. (Royal College of Forestry monograph, no 59).

2. Barnes R, Longley EO, Smith ARB, Allen JG. Vibration disease. Med J Aust 1 (1969) 901-905.
3. Forestry Agency, Ministry of Agriculture, Forestry and Fishers, Japan. Health care classification of vibration syndrome [in Japanese]. Tokyo 1978.

4. Futatsuka M. Studies on vibration hazards due to chain saw [in Japanese]. Kumamoto Med J 43 (1969) 467-524. (English summary).

5. Ichiba K, Aoki Y, Takagaki Y, Tomii S, Tamai S, Iwasaki H, Shirai T. Occupational hazards from the vibrations of forestry tools in Nara prefecture [in Japanese]. J Nara Med Assoc 26 (1980) 137-143. (English summary).

6. Iwata H, Katagiri Y, Kotani A. Vibration syndrome in a mountain village chain saw operators [in Japanese]. Gifu Med Rep 22 (1974) 479-484. (English summary).

7. Kylin B, Gerhardsson J, Lidström G, Hansson J-E, Lidström S, Liljenberg B, Swensson Å, Åstrand 1 . Hälso- och miljöundersökning bland skogsarbetare [Study of the health and work environment of lumberjacks]. AI-Rapport 5 (1968) 44-62. (English summary).

8. Loriga G. Il lavaro con i martelli pneumatici. Boll Ispett Lav 2 (1911) 35.

9. McCallum RI. Vibration syndrome. $\mathrm{Br} \mathrm{J}$ Ind Med 28 (1971) 90-93.

10. Miura T, Kimura K, Tominaga Y, Kimotsuki K. On the Raynaud's phenomenon of occupational origin due to vibrating tools [in Japanese]. J Sci Lab 42 (1966) 725-747. (English summary).

11. Miura T, Tominaga Y, Kimotsuki K. Relation between hours of the hand-arm-system vibration and vibration syndrome of workers (part 1) [in Japanese]. J Sci Lab 54 (1978) 297-314. (English summary).

12. Miyashita $\mathrm{K}$, Shiomi S, Itoh N, Kasamatsu T, Iwata $H$. Epidemiological study of vibration syndrome in response to total hand-tool operating time. Br J Ind Med 40 (1983) 92-98.

13. Pyykkö I. The prevalence and symptoms of traumatic vasospastic disease among lumberjacks in Finland. Work Environ Health 11 (1974) 118-131.

14. Saito K. Vibration hazards in Hokkaido and criteria for diagnosis of vibration disease [in Japanese]. J North Occup Health 33 (1978) 69-72.

15. Saito K. Vibration hazards as an occupational disease [in Japanese]. First edition. Nankodo, Tokyo 1980.

16. Taylor W, Pearson J, Kell RL, Keighley GD. Vibration syndrome in forestry commission chain saw operators. $\mathrm{Br}$ J Ind Med 28 (1971) 83-89.

17. Yamada S. Primary factors for the occurrence of white waxy changes of the finger in vibration hazards with presentation of the nail press test [in Japanese]. Jpn J Ind Health 14 (1972) 529-541. (English summary). 